I. М. Коротков, завідувач сектору фізико-хімічних досліджень відділу досліджень матеріалів, речовин і виробів, Кіровоградський науково-дослідний експертнокриміналістичний иентр МВС України, м. Кропивницький ORCID: https://orcid.org/0000-0002-6382-7780

\title{
КОМПЛЕКСНЕ ЗАСТОСУВАННЯ ГРАВІМЕТРИЧНОГО I ТИТРИМЕТРИЧНОГО МЕТОДІВ АНАЛІЗУ ПІД ЧАС ДОСЛІДЖЕННЯ ПРЕКУРСОРІВ У МЕЖАХ СУДОВОЇ ЕКСПЕРТИЗИ
}

\begin{abstract}
Meта статті - на основі теоретичних узагальнень і практики комплексного застосування гравіметричного і титриметричного методів аналізу на прикладі трикомпонентної суміші сульфатної та хлоридної кислот у водному розчині розробити методику визначення їх масової частки як необхідного і важливого етапу достовірного криміналістичного оцінювання результатів дослідження. Методологія. Достовірність отриманих результатів і висновків забезпечено використанням загальнонаукових і спеціальних методів дослідження. Зокрема, теоретичними методами (аналіз, синтез, порівняння, узагальнення) систематизовано матеріали, що становлять теоретичну базу дослідження, емпіричними (спостереження, вимірювання, порівняння, експеримент) проведено експериментальні дослідження для з'ясування доцільності використання гравіметричного та титриметричного методів аналізу під час визначення масової частки неорганічних кислот. За допомогою спеціальних статистичного та математичного методів дослідження розраховано як масову частку складових досліджуваних сумішей, так і похибку досліджень. У цілому застосування комплексу методів дозволило дійти висновку про придатність гравіметричного і титриметричного методів аналізу для визначення вмісту неорганічних кислот у трикомпонентних сумішах. Наукова новизна. Обгрунтовано можливість комплексного застосування гравіметричного і титриметричного методів аналізу для визначення у трикомпонентній суміші масової частки двох сильних кислот (сульфатної і хлоридної) у водному розчині як необхідного і важливого етапу достовірного криміналістичного оцінювання результатів дослідження. Висновки. Комплексне застосування в межах експерименту гравіметричного і титриметричного методів аналізу для визначення масової частки у трикомпонентній суміші двох сильних кислот (сульфатної та хлоридної) у водному розчині підтвердило можливість їх використання для вирішення експертних завдань. Основними перевагами пропонованих до використання гравіметричного і титриметричного методів аналізу є доступність обладнання, простота, технологічність, достатньо висока точність, що засвідчують доцільність їх застосування для визначення індивідуальних концентрацій неорганічних кислот із метою вирішення питання щодо вжиття заходів контролю за їх обігом. Окреслено основні засади і принципи методики визначення вмісту сульфатної та хлоридної кислот у трикомпонентній суміші, що слугуватиме підгрунтям для подальшого розроблення методичних рекомендацій у цьому напрямі. До того ж здійснено підбір основних параметрів реагентів і запропоновано методику для кількісного аналізу індивідуальних компонентів (неорганічних кислот) сумішей (розчинів) сульфатної та хлоридної кислот у трикомпонентній суміші, що базується на їх послідовному розділенні й дозволяє отримати значення їх масової частки 3 відносними похибками 2,4 \% для сульфатної та 4,6 \% для хлоридної, що в межах допустимої похибки вимірювання $\left(\Delta_{\mathrm{xmax}} \leq 3 \sigma\right)$.

Ключові слова: судова експертиза; прекурсори; сульфатна кислота; хлоридна кислота; гравіметричний метод аналізу; титриметричний метод аналізу; масова частка.
\end{abstract}

\section{Вступ}

Для дослідження за напрямом судової експертизи матеріалів, речовин і виробів до експертних установ надходять речовини, щодо яких залежно від їх концентрації можуть вживатися заходи контролю. Такими $є$ й фактично незамінні як у виробничо-економічній діяльності (металургія, харчове виробництво, медицина тощо), так і в побуті неорганічні кислоти, наприклад сульфатна та хлоридна, що також використовуються як прекурсори на різних стадіях виготовлення майже всіх наркотичних засобів і психотропних речовин, зокрема й героїну, кокаїну, амфетаміну, метамфетаміну, фенциклідину, фентанілу та ін.

Неорганічні кислоти надходять (такі об'єкти досліджують експерти, індекс експертної спеціальності яких - 8.6 «Дослідження наркотичних засобів, психотропних речовин, ї аналогів та прекурсорів») переважно у вигляді індивідуальних водних двокомпонентних сумішей. Але частина з них містить сильну та слабку кислоти або дві сильні кислоти, що ускладнює процес визначення концентрації кожної складової. Саме тому створення точної, відтворюваної, експресної та простої методики визначення масової частки, зокрема сульфатної та хлоридної кислот, $є$ необхідним i важливим етапом достовірного криміналістичного оцінювання результатів дослідження.

Концептуальні засади використання спеціальних знань у кримінальному судочинстві 
висвітлювали у своїх працях В. П. Бахін, В. Г. Гончаренко, А. В. Іщенко, Н. І. Клименко, В. О. Коновалова, Є. Д. Лук'янчиков, М. В. Салтевський, М. Я. Сегай, інші провідні вчені.

Окремі аспекти у цьому напрямі вивчали науковці і практики, як-от: поняття та правове регулювання використання спеціальних знань, умінь і навичок у кримінальному провадженні (Hribov, 2019); поняття та співвідношення спеціальних і криміналістичних знань при розслідуванні кримінальних правопорушень (Korchahina, 2020); принципи застосування спеціальних знань у кримінальному провадженні (Marushev, 2020); відповідність законодавства України про кримінальну відповідальність у сфері незаконного обігу наркотиків міжнародним нормативно-правовим актам (Danylevskyi, \& Danylevska, 2020); прекурсори та хімічні речовини, часто використовувані в незаконному виготовленні наркотичних засобів і психотропних речовин (International Narcotics Control Board, 2020); оновлення міжнародної парадигми регулювання вживання наркотиків (Turiansky, 2020).

Вітчизняні вчені плідно працюють над питаннями якісного (Hyrlia, \& Kelina, 2012; Tsyhanok, Bubel, Vyshnikin, \& Vashkevych, 2014; Chebotarov, Shcherbakova, \& Huzenko, 2015), а також кількісного (Alemasova, Zaitsev, Yenalieva, Shchepina, \& Hozhdzinskyi, 2010) хімічного аналізу неорганічних кислот.

Вагомий внесок у становлення та розвиток наукових засад неорганічної хімії зробили закордонні колеги (Woodridge, 1958; Deno, 1964; Charlot, \& Trémillon, 1969; Christian, \& Rosenthal, 1975; Brastad, \& Nathanson, 2011; Fraenkel, 2012, 2015; Mella, 2013; Najafizadeh-Sari, Baghdasht, Ramezani, \& Khoshmohabat, 2018; Manalastas, Kumar, Verma, Zhang, Yuan, \& Srinivasan, 2019; Li, \& Swanson, 2020).

При цьому питання комплексного застосування гравіметричного і титриметричного методів аналізу під час дослідження прекурсорів у межах судової експертизи не висвітлювались, а тому потребують грунтовного вивчення, зумовлюючи актуальність обраної тематики.

\section{Мета й завдання дослідження}

Мета статті - на основі теоретичних узагальнень і практики комплексного застосування гравіметричного і титриметричного методів аналізу на прикладі трикомпонентної суміші сульфатної та хлоридної кислот у водному розчині розробити методику визначення їх масової частки як необхідного і важливого етапу достовірного криміналістичного оцінювання результатів дослідження.

Для досягнення зазначеної мети потрібно вирішити такі завдання:

оцінити можливість комплексного застосу- вання гравіметричного і титриметричного методів аналізу під час дослідження прекурсорів у межах судової експертизи;

окреслити переваги комплексного застосування гравіметричного і титриметричного методів аналізу під час визначення кількісного складу індивідуальних компонентів (неорганічних кислот), одночасно присутніх у багатокомпонентних сумішах, і довести доцільність їх використання;

виокремити основні засади і принципи методики визначення вмісту сульфатної та хлоридної кислот у трикомпонентній суміші.

\section{Виклад основного матеріалу}

Прекурсорами наркотичних засобів і психотропних речовин відповідно до законодавства України є речовини, використовувані для виробництва, виготовлення наркотичних засобів і психотропних речовин, що внесені до Переліку наркотичних засобів, психотропних речовин і прекурсорів (Pro narkotychni zasoby, psykhotropni rechovyny i prekursory: Zakon Ukrainy, 1995, st. 1, abz. 18).

Відповідно неорганічні сульфатна і хлоридна кислоти належать до прекурсорів (Konventsiia Orhanizatsii Obiednanykh Natsii pro borotbu proty nezakonnoho obihu narkotychnykh zasobiv i psykhotropnykh rechovyn, 1988, dodatok, tabl. II; Organizatciia Obedinennykh Natcii, 2020), щодо яких вживають заходів контролю, коли їх масова частка у складі суміші (розчину) не менш як 45 \% для сульфатної та 15 \% для хлоридної кислоти (Perelik narkotychnykh zasobiv, psykhotropnykh rechovyn i prekursoriv: zatv. postanovoiu Kabinetu Ministriv Ukrainy № 770, 2000, tabl. IV, spysok № 2). Тому точність визначення концентрації (масової частки) цих кислот у складі суміші (розчину) та наявність чіткої методики iì вимірювання набуває ваги.

Процес дослідження водних розчинів кислот, зокрема хлоридної та сульфатної, оцінювання його результатів продемонструймо на прикладі визначення вмісту компонентів тестової суміші водного розчину $10 \%$ хлоридної та 40 \% сульфатної кислот, що слугує підгрунтям подальших експертних досліджень об'єктів у вигляді водного розчину цих кислот.

Для визначення вмісту сульфатної кислоти в розчині використовували гравіметричний метод аналізу, який базується на осадженні розчином нітрату барію сульфат-іонів у вигляді сульфату барію (хлоридна кислота при цьому в реакцію 3 реагентом не вступає, залишаючись у розчині):

$$
\mathrm{Ba}\left(\mathrm{NO}_{3}\right)_{2}+\mathrm{H}_{2} \mathrm{SO}_{4} \rightarrow \mathrm{BaSO}_{4} \downarrow+2 \mathrm{HNO}_{3}
$$

Сульфат барію цілком відповідає вимогам, які ставлять до осадів: його добуток розчинності 
$1,1 \cdot 10^{-10}$; осад практично не розчиняється в кислотах (Lure, 1989), має чітко визначений склад, що відповідає молекулярній формулі $\mathrm{BaSO}_{4}$, а отже під час прожарювання не змінюється. Відповідно ця сполука є гравіметричною формою, тобто в цьому визначенні гравіметрична форма збігається $з$ осаджувальною (Aleksandrova, \& Gaidukova, 2019). Крім того, слід зважати на те, що кристали $\mathrm{BaSO}_{4}$ дуже дрібні й під час фільтрування можуть проходити через пори фільтра, а також легко за- бруднюються сторонніми іонами з розчину. Саме тому важливими умовами укрупнення кристалів і їх чистоти $є$ повільне додавання осаджувача (Vasilev, 2009).

Методика гравіметричного визначення вмісту сульфатної кислоти передбачає шість етапів дослідження: підготовка тигля; підготовка проби до аналізу; осадження; фільтрування та промивання осаду; висушування та прожарювання; оцінювання результатів аналізу (табл. 1).

\section{Методика гравіметричного визначення вмісту сульфатної кислоти}

Таблиця 1

\begin{tabular}{|c|c|c|}
\hline $\begin{array}{c}\text { Етап } \\
\text { дослідження }\end{array}$ & Методика дослідження & Обладнання та реактиви \\
\hline $\begin{array}{l}\text { Підготовка } \\
\text { тигля }\end{array}$ & $\begin{array}{l}\text { Помити і висушити тигель, поставити в муфельну піч на } \\
20-25 \text { хв за } t=500{ }^{\circ} \mathrm{C} \text {, охолодити в ексикаторі, зважити на ана- } \\
\text { літичних вагах }\end{array}$ & $\begin{array}{l}\text { Піч муфельна, ваги } \\
\text { аналітичні, тигель, щипці, } \\
\text { ексикатор }\end{array}$ \\
\hline $\begin{array}{l}\text { Підготовка } \\
\text { проби до ана- } \\
\text { лізу }\end{array}$ & $\begin{array}{l}\text { Помістити в бюкс близько } 0,5 \text { г досліджуваного тестового роз- } \\
\text { чину, провести зважування. Наважку кількісно перенести в хі- } \\
\text { мічну склянку на } 100 \text { см}^{3} \text {, промити бюкс тричі дистильованою } \\
\text { водою, змиви перенести в склянку та розбавити розчин до } \\
50 \text { см³ дистильованою водою }^{3}\end{array}$ & $\begin{array}{l}\text { Ваги аналітичні, бюкс, } \\
\text { хімічна склянка, } \\
\text { скляна паличка, об'єкт } \\
\text { дослідження (тестовий } \\
\text { розчин), дистильована вода }\end{array}$ \\
\hline Осадження & $\begin{array}{l}\text { Отриманий розчин нагріти, не доводячи до кипіння. У хімічну } \\
\text { склянку мірним циліндром відібрати } 10 \mathrm{~cm}^{3} \text { розчину } \mathrm{Ba}\left(\mathrm{NO}_{3}\right)_{2} \\
(0,5 \mathrm{M}) \text {, нагріти і дуже повільно, краплями, безперервно перемі- } \\
\text { шуючи, долити цей гарячий розчин } \mathrm{Ba}\left(\mathrm{NO}_{3}\right)_{2} \text { у знятий із плитки } \\
\text { досліджуваний розчин. Дати осаду осісти і перевірити повноту } \\
\text { осадження, для чого по стінці склянки з осадом додати кілька } \\
\text { крапель Ва }\left(\mathrm{NO}_{3}\right)_{2} \text { і подивитися, чи не з'явиться каламуть. У разі } \\
\text { iї появи додати ще } 5 \mathrm{~cm}^{3} \mathrm{Ba}\left(\mathrm{NO}_{3}\right)_{2} \text { і знову перевірити на повноту } \\
\text { осадження. Провести центрифугування отриманої суміші }\end{array}$ & $\begin{array}{l}\text { Хімічна склянка -2 шт., } \\
\text { скляна паличка, мірний } \\
\text { циліндр - } 2 \text { шт., плитка } \\
\text { електрична, розчин } \\
\mathrm{Ba}\left(\mathrm{NO}_{3}\right)_{2}(0,5 \mathrm{M}), \\
\text { досліджувана суміш }\end{array}$ \\
\hline $\begin{array}{l}\text { Фільтрування } \\
\text { та промивання } \\
\text { осаду }\end{array}$ & $\begin{array}{l}\text { Фільтрування здійснити через щільний беззольний фільтр «синя } \\
\text { стрічка». Після злиття зі склянки всього розчину на фільтр осад, } \\
\text { що в склянці, промити декантацією. Для цього налити в склянку } \\
10-20 \text { см}^{3} \text { дистильованої води, додати } 3-4 \text { краплі } \mathrm{HNO}_{3}(0,1 \mathrm{M}) \text {. } \\
\text { Осад розмішати скляною паличкою, дати відстоятися. Прозо- } \\
\text { рий розчин злити на фільтр. Промивання повторити двічі-три- } \\
\text { чі, після чого осад кількісно перенести на фільтр. На фільтрі } \\
\text { осад промити } 10 \text { мл води для видалення іонів } \mathrm{NO}_{3}^{-}\end{array}$ & $\begin{array}{l}\text { Хімічна склянка, } \\
\text { скляна паличка, } \\
\text { мірний циліндр, піпетка, } \\
\text { лійка, конічна колба, } \\
\text { фільтр «синя стрічка», } \\
\text { розчин } \mathrm{HNO}_{3}(0,1 \mathrm{M}), \\
\text { дистильована вода }\end{array}$ \\
\hline $\begin{array}{l}\text { Висушування } \\
\text { та прожарю- } \\
\text { вання }\end{array}$ & $\begin{array}{l}\text { Помістити фільтр з осадом у підготовлений тигель, поставити } \\
\text { в муфельну піч за } t=500 \text { C на } 20 \text { хв, після чого в ексикатор. Охо- } \\
\text { лоджений тигель зважити на аналітичних вагах, записати його } \\
\text { масу і знову поставити в муфельну піч на } 10 \text { хв, охолодити і зва- } \\
\text { жити. Якщо різниця між зважуваннями не перевищує } 0,0002 \text { г, } \\
\text { можна вважати, що осад доведений до постійної маси. В іншому } \\
\text { разі операцію з прожарювання повторюють до досягнення по- } \\
\text { стійної маси }\end{array}$ & $\begin{array}{l}\text { Аналітичні ваги, тигель, } \\
\text { осад } \mathrm{BaSO}_{4} \text {, муфельна піч, } \\
\text { ексикатор }\end{array}$ \\
\hline $\begin{array}{l}\text { Оцінювання } \\
\text { результатів } \\
\text { аналізу }\end{array}$ & $\begin{array}{l}\text { Обчислити вміст сульфатної кислоти у відсотках, розрахувати } \\
\text { похибку }\end{array}$ & \\
\hline
\end{tabular}


Масову частку сульфатної кислоти обчислюють за формулою:

де: $\quad m$ - маса осаду, г;

$$
w=\frac{m \cdot F \cdot 100 \%}{g}
$$

$F$ - фактор перерахунку;

$g$ - маса наважки, г.

За результат визначення вмісту сульфатної кислоти брали середнє арифметичне результатів п’яти паралельних визначень - 39,05 \% (табл. 2).

Таблиця 2

Масова частка сульфатної кислоти в розчині

\begin{tabular}{c|c}
\hline Маса отриманого осаду, $\mathbf{r}$ & ${\text { Масова частка } \mathbf{H}_{2} \mathbf{S O}_{4}, \mathbf{\%}}^{\mathbf{2}}$ \\
\hline 0,4712 & 39,58 \\
0,4549 & 38,21 \\
0,4775 & 40,11 \\
0,4641 & 38,98 \\
0,4568 & 38,37
\end{tabular}

Здійснили статистичне оброблення результатів аналізу (Derffel, 1994) із використанням можливостей Microsoft Excel (табл. 3).

Таблиця 3

Статистичний аналіз результатів дослідження

\begin{tabular}{c|c}
\hline Параметр & Показник \\
\hline Середнє значення, \% & 39,05 \\
Абсолютна похибка вимірювання, \% & 0,95 \\
Відносна похибка вимірювання, \% & 2,4 \\
Дисперсія & 0,64 \\
Стандартне відхилення, \% & 0,8 \\
Відносне стандартне відхилення, \% & 2,1 \\
Довірчий інтервал, \% & $39,05 \pm 0,99$
\end{tabular}

Як свідчать результати дослідження, отримане значення вмісту сульфатної кислоти в суміші близьке до істинного та не виходить за межі максимальної похибки вимірювання, а отже допустиме, і визначення масової частки сульфатної кислоти гравіметричним методом $€$ доцільним.

Масову частку хлоридної кислоти вимірювали в отриманому на попередньому етапі дослідження фільтраті методом Фольгарда: до фільтрату додавали точно відміряний надлишок $0,1 \mathrm{M}$ розчину нітрату срібла $\mathrm{AgNO}_{3}$. Титрування проводили без відділення осаду $\mathrm{AgCl}$, тому до отриманої суміші додавали 5-10 мл нітробензолу. Суміш добре збовтували упродовж 30-40 с (при цьому осад $\mathrm{AgCl}$ набував пластівчастої будови і захоплювався нітробензолом). До розчину додавали 2 мл насиченого розчину залізоамонійних галунів і титрували 0,1 М розчином тіоціанату амонію при легкому перемішуванні до появи слабкого червоно-бурого забарвлення (Kharitonov, 2014; Pilipenko, \& Piatnitckii, 1990).
Розраховували масову частку хлоридної кислоти за формулою:

$$
X=\frac{\left(V_{\mathrm{AgNO}_{3}} k-V_{\mathrm{NH}_{4} C N S} k\right) T}{m_{\text {наважки }}} 100 \%,
$$

де:

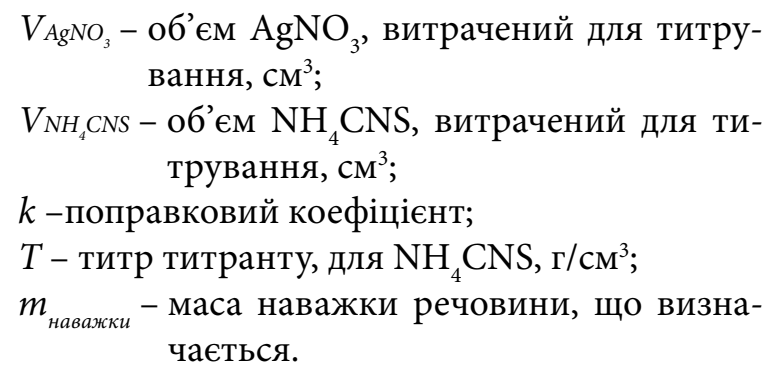

За результат визначення вмісту хлоридної кислоти брали середнє арифметичне результатів п'яти паралельних визначень, що становить 9,56 \% (табл. 4). 
Таблиця 4

Масова частка хлоридної кислоти в розчині

\begin{tabular}{c}
\hline Масова частка $\mathbf{H C l}, \%$ \\
\hline 10,05 \\
9,33 \\
9,45 \\
9,17 \\
9,78
\end{tabular}

Здійснили статистичне оброблення результатів аналізу (Derffel, 1994) (табл. 5).

Таблиця 5

Статистичний аналіз результатів дослідження

\begin{tabular}{c|c}
\hline Параметр & Показник \\
\hline Середнє значення, \% & 9,56 \\
Абсолютна похибка вимірювання, \% & 0,44 \\
Відносна похибка вимірювання, \% & 4,6 \\
Дисперсія & 0,13 \\
Стандартне відхилення, \% & 0,36 \\
Відносне стандартне відхилення, \% & 3,8 \\
Довірчий інтервал (t-розподіл Стьюдента), \% & $9,56 \pm 0,45$
\end{tabular}

Як і за підрахунку вмісту сульфатної кислоти, отримане значення вмісту хлоридної кислоти в суміші близьке до істинного та не виходить за межі максимальної похибки вимірювання. Відповідно використання для підрахунку методу Фольгарда (за умови попереднього відділення хлоридної кислоти від тестової трикомпонентної суміші) дозволяє отримати задовільний результат.

\section{Наукова новизна}

Обгрунтовано можливість комплексного застосування гравіметричного і титриметричного методів аналізу для визначення у трикомпонентній суміші масової частки двох сильних кислот (сульфатної і хлоридної) у водному розчині як необхідного і важливого етапу достовірного криміналістичного оцінювання результатів дослідження.

\section{Висновки}

1. Комплексне застосування в межах експерименту гравіметричного i титриметричного методів аналізу для визначення масової частки у трикомпонентній суміші двох сильних кислот (сульфатної та хлоридної) у водному розчині під- твердило можливість їх використання для вирішення експертних завдань.

2. Основними перевагами пропонованих до використання гравіметричного і титриметричного методів аналізу є доступність обладнання, простота, технологічність, достатньо висока точність, що засвідчують доцільність їх застосування для визначення індивідуальних концентрацій неорганічних кислот із метою вирішення питання щодо вжиття заходів контролю за їх обігом.

3. Окреслено основні засади і принципи методики визначення вмісту сульфатної та хлоридної кислот у трикомпонентній суміші, що слугуватиме підгрунтям для подальшого розроблення методичних рекомендацій у цьому напрямі. До того ж здійснено підбір основних параметрів реагентів і запропоновано методику для кількісного аналізу індивідуальних компонентів (неорганічних кислот) сумішей (розчинів) - сульфатної та хлоридної кислот у трикомпонентній суміші, що базується на їх послідовному розділенні й дозволяє отримати значення їх масової частки з відносними похибками 2,4 \% для сульфатної та 4,6 \% для хлоридної, що в межах допустимої похибки вимірювання $\left(\Delta_{\text {хmax }} \leq 3 \sigma\right)$. 


\section{References}

Aleksandrova, E. A., \& Gaidukova, N. G. (2019). Analiticheskaia khimiia: v 2-kh kn. Kn. 1. Khimicheskie metody analiza: ucheb. i praktikum dlia priklad. bakalavriata. (3-e izd., ispr. i dop.). M.: Iurait. 537 s. [in Russian].

Alemasova, A. S., Zaitsev, V. M., Yenalieva, L. Ya., Shchepina, N. D., \& Hozhdzinskyi, S. M. (2010). Analitychna khimiia: pidruch. dlia vyshchykh navch. zakladiv. Donetsk: Noulidzh. 141 s. [in Ukrainian].

Brastad, S. M., \& Nathanson, G. M. (2011). Molecular beam studies of $\mathrm{HCl}$ dissolution and dissociation in cold salty water. Physical Chemistry Chemical Physics, 13 (18), 8284-8295.

DOI: https://doi.org/10.1039/c0cp02540b.

Charlot, G., \& Trémillon, B. (1969). Acid-base reactions in polar solvents. Chemical Reactions in Solvents and Melts. P. 45-85. DOI: https://doi.org/10.1016/B978-0-08-012678-4.50006-3.

Chebotarov, O. M., Shcherbakova, T. M., \& Huzenko, O. M. (2015). Analitychna khimiia. Yakisnyi ta kilkisnyi analiz: metodychni vkazivky do laboratornykh robit dlia studentiv I-II kursiv zaochnoho viddilennia khimichnoho ta biolohichnoho fakultetiv. Odesa: Odeskyi nats. un-t imeni I. I. Mechnykova. 84 s. [in Ukrainian].

Christian, G. D., \& Rosenthal, D. (1975). The Effects of Salts on Titrations. CR C Critical Reviews in Analytical Chemistry, 5 (2), 119-163.

DOI: https://doi.org/10.1080/10408347508542682.

Danylevskyi, A. O., \& Danylevska, Yu. O. (2020). Shchodo vidpovidnosti zakonodavstva Ukrainy pro kryminalnu vidpovidalnist u sferi nezakonnoho obihu narkotykiv mizhnarodnym normatyvno-pravovym aktam. Pravovyi chasopys Donbasu, 4 (73), 95-102 [in Ukrainian].

DOI: https://doi.org/10.32366/2523-4269-2020-73-4-95-102.

Deno, N. C. (1964). Equilibria in Concentrated Mineral Acid Solutions. Survey of Progress in Chemistry, 2, 155-187. DOI: https://doi.org/10.1016/B978-1-4832-0004-0.50009-1.

Derffel, K. (1994). Statistika v analiticheskoi khimii. M.: Mir. 268 s. [in Russian].

Fraenkel, D. (2012). Electrolytic Nature of Aqueous Sulfuric Acid. 1. Activity. The Journal of Physical Chemistry, 116 (38), $11662-11677$.

DOI: https://doi.org/10.1021/jp3060334.

Fraenkel, D. (2015). Structure and ionization of sulfuric acid in water. New Journal of Chemistry, 39 (7), 5124-5136. DOI: https://doi.org/10.1039/C5NJ00167F.

Hribov, M. (2019). Poniattia ta pravove rehuliuvannia vykorystannia spetsialnykh znan, umin i navychok u kryminalnomu provadzhenni. Naukovyi visnyk Natsionalnoi akademii vnutrishnikh sprav, 110 (1), 13-21. [in Ukrainian]. DOI: https://doi.org/10.33270/01191101.13.

Hyrlia, L. M., \& Kelina, S. Yu. (2012). Analitychna khimiia: navch. posib. Mykolaiv: MDAU. 247 s. [in Ukrainian].

International Narcotics Control Board. (2020). Precursors and chemicals frequently used in the illicit manufacture of narcotic drugs and psychotropic substances 2019.

DOI: https://doi.org/10.18356/3c7f75e8-fr.

Kharitonov, Iu. Ia. (2014). Analiticheskaia khimiia. Analitika 2. Kolichestvennyi analiz. Fiziko-khimicheskie (instrumentalnye) metody analiza. M.: GEOTAR-Media. $656 \mathrm{~s}$. [in Russian].

Konventsiia Orhanizatsii Obiednanykh Natsii pro borotbu proty nezakonnoho obihu narkotychnykh zasobiv i psykhotropnykh rechovyn. (1988). Uziato $\mathrm{z}$ https://zakon.rada.gov.ua/laws/show/995_096\#Text.

Korchahina, A. M. (2020). Poniattia ta spivvidnoshennia spetsialnykh ta kryminalistychnykh znan pry rozsliduvanni kryminalnykh pravoporushen. Tekhnolohii, instrumenty ta stratehii realizatsii naukovykh doslidzhen: materialy konferentsii. Kherson: MTsND. 154-156. [in Ukrainian].

DOI: https://doi.org/10.36074/20.03.2020.16.

Li, Ch., \& Swanson, J. M. J. (2020). Understanding and Tracking the Excess Proton in Ab Initio Simulations; Insights from IR Spectra. The Journal of Physical Chemistry, 124 (27), 5696-5708.

DOI: https://doi.org/10.1021/acs.jpcb.0c03615.

Lure, Iu. Iu. (1989). Spravochnik po analiticheskoi khimii. M.: Khimiia. 448 s. [in Russian].

Manalastas, W., Kumar, S., Verma, V., Zhang, L., Yuan, D., \& Srinivasan, M. (2019). Water in Rechargeable Multivalent-Ion Batteries: An Electrochemical Pandora’s Box. ChemSusChem, 12 (2), 379-396.

DOI: https://doi.org/10.1002/cssc.201801523.

Marushev, A. D. (2020). Pryntsypy zastosuvannia spetsialnykh znan u kryminalnomu provadzhenni. Aktualni problemy derzhavy i prava, 86, 139-144 [in Ukrainian].

DOI: https://doi.org/10.32837/apdp.v0i86.2424.

Mella, M. (2013, Jen.). Exploring unvisited regions to investigate solution properties: The backyard of $\mathrm{H}_{3} \mathrm{O}^{+}$and its aggregates. Chemical Physics Letters, 555, 51-56. DOI: https://doi.org/10.1016/j.cplett.2012.10.078.

Najafizadeh-Sari, Sh., Baghdasht, M. S. B., Ramezani, A., \& Khoshmohabat, H. (2018, March). Awareness of Toxicity Induced by Chlorine. Trauma Monthly, 23 (2), 1-2. DOI: https://doi.org/10.5812/traumamon.62862.

Organizatciia Obedinennykh Natcii. (2020). Prekursory i khimicheskie veshchestva, chasto ispolzuemye pri nezakonnom izgotovlenii narkoticheskikh sredstv i psikhotropnykh veshchestv: doklad Mezhdunarodnogo komiteta po kontroliu 
nad narkotikami za 2019 god o vypolnenii stati 12 Konventcii Organizatcii Obedinennykh Natcii o borbe protiv nezakonnogo oborota narkoticheskikh sredstv i psikhotropnykh veshchestv 1988 goda. Vena. $155 \mathrm{~s}$. Vziato iz https:// unis.unvienna.org/pdf/2020/INCB/Precursors_R.pdf. [in Russian].

Perelik narkotychnykh zasobiv, psykhotropnykh rechovyn i prekursoriv: zatv. postanovoiu Kabinetu Ministriv Ukrainy № 770. (2000). Uziato z https://zakon.rada.gov.ua/laws/show/770-2000-p\#top [in Ukrainian].

Pilipenko, A. T., \& Piatnitckii, I. V. (1990). Analiticheskaia khimiia: v 2 kn. Kn. 1: ucheb. posobie. M.: Khimiia. 480 s. [in Russian].

Pro narkotychni zasoby, psykhotropni rechovyny i prekursory: Zakon Ukrainy № 60/95-VR. (1995). Uziato z zakon.rada. gov.ua/laws/show/60/95-vr. [in Ukrainian].

Tsyhanok, L. P., Bubel, T. O., Vyshnikin, A. B., \& Vashkevych, O. Yu. (2014). Analitychna khimiia. Khimichni metody analizu: navch. posib. Dnipropetrovsk: DNU im. O. Honchara. 252 s. [in Ukrainian].

Turiansky, Y. (2020). Updating the international paradigm of regulation of using drug: towards the problem. Academic Journals and Conferences (Vol. 7, 1 (25), p. 83-88). Retrieved from http://science.lpnu.ua/law/all-volumes-and-issues/ volume-7-number-25-2020/updating-international-paradigm-regulation-using.

Vasilev, V. P. (2009). Analiticheskaia khimiia: v 2-kh kn. Kn. 1. Titrimetricheskie i gravimetricheskii metody analiza: ucheb. dlia stud. vuzov, obuchaiushchikhsia po khimiko-tekhnol. spetc. (7-e izd., stereotip.). M.: Drofa. 308 s. [in Russian].

Woodridge, J. E. (1958). Theoretical aspects of sulfonation and sulfation. Journal of the American Oil Chemists' Society, $35(10), 528-531$.

DOI: https://doi.org/10.1007/BF02637955.

\section{Список використаних джерел}

Александрова, Э. А., \& Гайдукова, Н. Г. (2019). Аналитическая химия: в 2-х кн. Кн. 1. Химические методы анализа: учеб. и практикум для приклад. бакалавриата. (3-е изд., испр. и доп.). М.: Юрайт. 537 с.

Алемасова, А. С., Зайцев, В. М., Єнальєва, Л. Я., Щепіна, Н. Д., \& Гождзінський, С. М. (2010). Аналітична хімія: підруч. для вищих навч. закладів. Донецьк: Ноулідж. 141 с.

Brastad, S. M., \& Nathanson, G. M. (2011). Molecular beam studies of $\mathrm{HCl}$ dissolution and dissociation in cold salty water. Physical Chemistry Chemical Physics, 13 (18), 8284-8295. DOI: https://doi.org/10.1039/c0cp02540b.

Charlot, G., \& Trémillon, B. (1969). Acid-base reactions in polar solvents. Chemical Reactions in Solvents and Melts. P. $45-85$.

DOI: https://doi.org/10.1016/B978-0-08-012678-4.50006-3.

Чеботарьов, О. М., Щербакова, Т. М., \& Гузенко, О. М. (2015). Аналітична хімія. Якісний та кількісний аналіз: методичні вказівки до лабораторних робіт для студентів I-II курсів заочного відділення хімічного та біологічного факультетів. Одеса: Одеський нац. ун-т імені I. I. Мечникова. 84 с.

Christian, G. D., \& Rosenthal, D. (1975). The Effects of Salts on Titrations. CR C Critical Reviews in Analytical Chemistry, 5 (2), $119-163$.

DOI: https://doi.org/10.1080/10408347508542682.

Данилевський, А. О., \& Данилевська, Ю. О. (2020). Щодо відповідності законодавства України про кримінальну відповідальність у сфері незаконного обігу наркотиків міжнародним нормативно-правовим актам. Правовий часопис Донбасу, 4 (73), 95-102.

DOI: https://doi.org/10.32366/2523-4269-2020-73-4-95-102.

Deno, N. C. (1964). Equilibria in Concentrated Mineral Acid Solutions. Survey of Progress in Chemistry, 2, $155-187$. DOI: https://doi.org/10.1016/B978-1-4832-0004-0.50009-1.

Дёрффель, К. (1994). Статистика в аналитической химии. М.: Мир. 268 с.

Fraenkel, D. (2012). Electrolytic Nature of Aqueous Sulfuric Acid. 1. Activity. The Journal of Physical Chemistry, 116 (38), $11662-11677$.

DOI: https://doi.org/10.1021/jp3060334.

Fraenkel, D. (2015). Structure and ionization of sulfuric acid in water. New Journal of Chemistry, 39 (7), 5124-5136. DOI: https://doi.org/10.1039/C5NJ00167F.

Грібов, М. (2019). Поняття та правове регулювання використання спеціальних знань, умінь і навичок у кримінальному провадженні. Науковий вісник Національної академії внутрішніх справ, 110 (1), 13-21. DOI: https://doi.org/10.33270/01191101.13.

Гирля, Л. М., \& Кельїна, С. Ю. (2012). Аналітична хімія: навч. посіб. Миколаїв: МДАУ. 247 с.

International Narcotics Control Board. (2020). Precursors and chemicals frequently used in the illicit manufacture of narcotic drugs and psychotropic substances 2019.

DOI: https://doi.org/10.18356/3c7f75e8-fr.

Харитонов, Ю. Я. (2014). Аналитическая химия. Аналитика 2. Количественный анализ. Физико-химические (инструментальные) методы анализа. М.: ГЭОТАР-Медиа. 656 с.

Конвенція Організації Об’єднаних Націй про боротьбу проти незаконного обігу наркотичних засобів і психотропних речовин. (1988). Узято з https://zakon.rada.gov.ua/laws/show/995_096\#Text.

Корчагіна, А. М. (2020). Поняття та співвідношення спеціальних та криміналістичних знань при розслідуванні 
кримінальних правопорушень. Технології, інструменти та стратегії реалізації наукових досліджень: матеріали конференціі. Херсон: МЦНД. 154-156.

DOI: https://doi.org/10.36074/20.03.2020.16.

Li, Ch., \& Swanson, J. M. J. (2020). Understanding and Tracking the Excess Proton in Ab Initio Simulations; Insights from IR Spectra. The Journal of Physical Chemistry, 124, (27), 5696-5708.

DOI: https://doi.org/10.1021/acs.jpcb.0c03615.

Лурье, Ю. Ю. (1989). Справочник по аналитической химии. М.: Химия. 448 с.

Manalastas, W., Kumar, S., Verma, V., Zhang, L., Yuan, D., \& Srinivasan, M. (2019). Water in Rechargeable Multivalent-Ion Batteries: An Electrochemical Pandora's Box. ChemSusChem, 12 (2), 379-396. DOI: https://doi.org/10.1002/cssc.201801523.

Марушев, А. Д. (2020). Принципи застосування спеціальних знань у кримінальному провадженні. Актуальні проблеми держави і права, 86, 139-144.

DOI: https://doi.org/10.32837/apdp.v0i86.2424.

Mella, M. (2013, Jen.). Exploring unvisited regions to investigate solution properties: The backyard of $\mathrm{H}_{3} \mathrm{O}^{+}$and its aggregates. Chemical Physics Letters, 555, 51-56. DOI: https://doi.org/10.1016/j.cplett.2012.10.078.

Najafizadeh-Sari, Sh., Baghdasht, M. S. B., Ramezani, A., \& Khoshmohabat, H. (2018, March). Awareness of Toxicity Induced by Chlorine. Trauma Monthly, 23 (2), 1-2. DOI: https://doi.org/10.5812/traumamon.62862.

Организация Объединенных Наций. (2020). Прекурсоры и химические вещества, часто используемье при незаконном изготовлении наркотических средств и психотропных веществ: доклад Международного комитета по контролю над наркотиками за 2019 год о выполнении статьи 12 Конвенции Организации Объединенных Наций о борьбе против незаконного оборота наркотических средств и психотропных веществ 1988 года. Вена. 155 с. Взято из https://unis.unvienna.org/pdf/2020/INCB/Precursors_R.pdf.

Перелік наркотичних засобів, психотропних речовин і прекурсорів: затв. постановою Кабінету Міністрів України № 770. (2000). Узято з https://zakon.rada.gov.ua/laws/show/770-2000-п\#top.

Пилипенко, А. Т., \& Пятницкий, И. В. (1990). Аналитическая химия: в 2 кн. Кн. 1: учеб. пособие. М.: Химия. 480 с. Про наркотичні засоби, психотропні речовини і прекурсори: Закон України № 60/95-BP. (1995). Узято $з$ zakon.rada. gov.ua/laws/show/60/95-вр.

Циганок, Л. П., Бубель, Т. О., Вишнікін, А. Б., \& Вашкевич, О. Ю. (2014). Аналітична хімія. Хімічні методи аналізу: навч. посіб. Дніпропетровськ: ДНУ ім. О. Гончара. 252 с.

Turiansky, Y. (2020). Updating the international paradigm of regulation of using drug: towards the problem. Academic Journals and Conferences (Vol. 7, 1 (25), p. 83-88). Retrieved from http://science.lpnu.ua/law/all-volumes-and-issues/ volume-7-number-25-2020/updating-international-paradigm-regulation-using.

Васильев, В. П. (2009). Аналитическая химия: в 2-х кн. Кн. 1. Титриметрические и гравиметрический методы анализа: учеб. для студ. вузов, обучающихся по химико-технол. спец. (7-е изд., стереотип.). М.: Дрофа. 308 с.

Woodridge, J. E. (1958). Theoretical aspects of sulfonation and sulfation. Journal of the American Oil Chemists'Society, 35 (10), 528-531.

DOI: https://doi.org/10.1007/BF02637955.

Стаття надійшла до редакції 29.01.2021

I. Korotkov, Head of Physicochemical Researches Sector,

Materials, Substances and Products Research Department,

Kirovohrad Scientific Research Forensic Center,

MIA of Ukraine, Kropyvnytskyi, Ukraine

ORCID: https://orcid.org/0000-0002-6382-7780

\section{IMPROVEMENT OF EXPERT RESEARCH OF PRECURSORS BY USING GRAVIMETRIC AND TITRIMETRIC METHODS OF ANALYSIS}

The purpose of the article is to develop a method of determining their mass fraction as a necessary and important stage of reliable forensic evaluation of research results on the basis of theoretical generalizations and practice of complex application of gravimetric and titrimetric methods of analysis on the example of three-component mixture of sulfuric and hydrochloric acids in aqueous solution. Methodology. The reliability of the obtained results and conclusions is ensured by the use of general scientific and special research methods. In particular, theoretical methods (analysis, synthesis, comparison, generalization) systematized the materials that make up the theoretical basis of the 
study, empirical (observation, measurement, comparison, experiment) conducted experimental studies to determine the feasibility of using gravimetric and titrimetric methods of analysis in determining mass particles of inorganic acids. With the help of special statistical and mathematical research methods, both the mass fraction of the components of the studied mixtures and the research error were calculated. In general, the use of a set of methods allowed us to conclude that the gravimetric and titrimetric methods of analysis for determining the content of inorganic acids in ternary mixtures. Scientific novelty. The possibility of complex application of gravimetric and titrimetric methods of analysis to determine the mass fraction of two strong acids (sulfuric and hydrochloric) in aqueous solution in a threecomponent mixture as a necessary and important stage of reliable forensic evaluation of research results is substantiated. Conclusions. The complex application of gravimetric and titrimetric methods of analysis within the experiment to determine the mass fraction in a three-component mixture of two strong acids (sulfuric and hydrochloric) in aqueous solution confirmed the possibility of using them to solve expert problems. The main advantages of the proposed gravimetric and titrimetric methods of analysis are the availability of equipment, simplicity, manufacturability, high enough accuracy, indicating the feasibility of their use to determine individual concentrations of inorganic acids to address measures to control their circulation. The main principles and principles of the method of determining the content of sulfuric and hydrochloric acids in the three-component mixture are outlined, which will serve as a basis for further development of methodological recommendations in this direction. In addition, the selection of the main parameters of the reagents and proposed a method for quantitative analysis of individual components (inorganic acids) mixtures (solutions) - sulfuric and hydrochloric acids in a three-component mixture, based on their sequential separation and allows to obtain values of their mass fraction with relative errors $2,4 \%$ for sulphate and $4,6 \%$ for chloride, which is within the allowable measurement error $(\Delta \mathrm{xmax} \leq 3 \sigma)$.

Keywords: forensic examination; precursors; sulfuric acid; hydrochloric acid; gravimetric method of analysis; titrimetric method of analysis; the mass fraction.

И. Н. Коротков, заведующий сектором физико-химических исследований отдела исследования материалов, веществ и изделий,

Кировоградский научно-исследовательский экспертно-

криминалистический иентр МВД Украины, г. Кропивниикий

ORCID: https://orcid.org/0000-0002-6382-7780

\title{
КОМПЛЕКСНОЕ ПРИМЕНЕНИЕ ГРАВИМЕТРИЧЕСКОГО И ТИТРИМЕТРИЧЕСКОГО МЕТОДОВ АНАЛИЗА В ХОДЕ ИССЛЕДОВАНИЯ ПРЕКУРСОРОВ В РАМКАХ СУДЕБНОЙ ЭКСПЕРТИЗЫ
}

\begin{abstract}
Цель статьи - на основе теоретических обобщений и практики комплексного применения гравиметрического и титриметрического методов анализа на примере трехкомпонентной смеси серной и соляной кислот в водном растворе разработать методику определения их массовой доли как необходимого и важного этапа достоверной криминалистической оценки результатов исследования. Методология. Достоверность полученных результатов и выводов обеспечена использованием общенаучных и специальных методов исследования. В частности, теоретическими методами (анализ, синтез, сравнение, обобщение) систематизированы материалы, составляющие теоретическую базу исследования, эмпирическими (наблюдение, измерение, сравнение, эксперимент) проведены экспериментальные исследования для выяснения целесообразности использования гравиметрического и титриметрического методов анализа при определении массовой доли неорганических кислот. С помощью специальных статистического и математического методов исследования рассчитаны как массовая доля составляющих исследуемой смеси, так и погрешность исследований. В целом применение комплекса методов позволило сделать вывод о пригодности гравиметрического и титриметрического методов анализа для определения содержания неорганических кислот в трехкомпонентных смесях. Научная новизна. Обоснована возможность комплексного применения гравиметрического и титриметрического методов анализа для определения в трехкомпонентной смеси массовой доли двух сильных кислот (серной и соляной) в водном растворе как необходимого и важного этапа достоверной криминалистической оценки результатов исследования. Bbыводы. Комплексное применение в рамках эксперимента гравиметрического и титриметрического методов анализа для определения массовой доли в трехкомпонентной смеси двух сильных кислот (серной и соляной) в водном растворе подтвердило возможность их использования для решения экспертных задач. Основными преимуществами предлагаемых к использованию гравиметрического и титриметрического методов анализа являются доступность оборудования, простота, технологичность, достаточно высокая точность, подтверждающие целесообразность их применения для определения индивидуальных концентраций неорганических кислот с целью решения вопроса о принятии мер контроля за их оборотом. Определены основные принципы методики определения содержания серной и соляной кислот в трехкомпонентной смеси, что может служить основой для дальнейшей разработки методических рекомендаций в этом направлении. К тому же осуществлен подбор основных параметров реагентов и предложена методика для количественно-
\end{abstract}


го анализа индивидуальных компонентов (неорганических кислот) смесей (растворов) - серной и соляной кислот в трехкомпонентной смеси, основанного на их последовательном разделении и который позволяет получить значение их массовой доли с относительными погрешностями 2,4 \% для серной и 4,6 \% для соляной, что в пределах допустимой погрешности измерения $(\Delta \mathrm{xmax} \leq 3 \sigma)$.

Ключевые слова: судебная экспертиза; прекурсоры; серная кислота; соляная кислота; гравиметрический метод анализа; титриметрический метод анализа; массовая доля. 